\title{
Bermudagrass Reseeding Intervals for Rimsulfuron, Simazine, and Sulfosulfuron
}

\author{
Patrick E. McCullough ${ }^{1,3}$ and William Nutt ${ }^{2}$ \\ Department of Crop and Soil Sciences, University of Georgia, Griffin, GA \\ 30223-1797
}

Additional index words. herbicide, turf, seed

\begin{abstract}
Turf managers may wish to reseed common bermudagrass [Cynodon dactylon (L.) Pers.] following weed control with rimsulfuron, simazine, or sulfosulfuron applications, but establishment may be affected by herbicide residual activity. Field experiments were conducted in Georgia to investigate bermudagrass reseeding intervals for these herbicides. Application timing before seeding reduced bermudagrass establishment more than herbicide rate. By four weeks after seeding, bermudagrass cover was $15 \%$, $53 \%, 81 \%$, and $90 \%$ of the untreated from herbicides applied zero, two, four, or six weeks before seeding, respectively. Simazine at $2.24 \mathrm{~kg}$ a.i./ha reduced bermudagrass cover more frequently than sulfosulfuron at 0.035 and $0.07 \mathrm{~kg}$ a.i./ha and rimsulfuron at $0.02 \mathrm{~kg}$ a.i./ha. Results suggest that common bermudagrass may be safely reseeded four to six weeks after rimsulfuron, simazine, or sulfosulfuron treatments, but applications made closer to the seeding date have the potential to significantly delay establishment.
\end{abstract}

Bermudagrass [Cynodon spp. (L.) Rich.] is the most popular turfgrass planted in warmhumid regions (Beard, 1973). Improved seeded cultivars of common bermudagrass [Cynodon dactylon (L.) Pers.] have color, quality, and texture comparable to hybrid bermudagrass (Cynodon dactylon $\times$ C. transvaalensis Burtt-Davy) (NTEP, 2008). Potential-to-seed common bermudagrass provides turf managers with an establishment option that is unavailable for vegetatively propagated hybrid bermudagrass and may allow practitioners to replant areas following weed control with herbicides (Beard, 1973). Cool-season grasses and winter annuals are often problematic weeds in bermudagrass during spring and early summer. Actively growing weeds may out-compete bermudagrass for light, water, and nutrients during dormancy or early spring growth (McCarty et al., 2005). Controlling winter weeds with herbicides may reduce weed competition during spring greenup and allow turf managers to establish a uniform bermudagrass turf. Nonselective herbicides, such as glyphosate or glufosinate, may be used to control weeds on completely dormant bermudagrass, but applications during spring greenup may cause unacceptable injury and stand loss (Toler et al., 2007). Thus, selective postemergence herbicides are used for weed control in spring as bermudagrass emerges from winter dormancy. Rimsulfuron and sulfosulfuron are sulfonylurea herbicides used for weed control in bermudagrass (Chaleff and Mauvais, 1984; Dupont, 2004; Monsanto,

\footnotetext{
Received for publication 5 Jan. 2010. Accepted for publication 4 Feb. 2010.

${ }^{1}$ Assistant Professor.

${ }^{2}$ Program Technician.

${ }^{3}$ To whom reprints request should be addressed; e-mail: pmccull@uga.edu.
}

2008). These herbicides effectively control grassy weeds, such as tall fescue (Festuca arundinacea Schreb.), perennial ryegrass (Lolium perenne L.), and roughstalk bluegrass (Poa trivialis L.), and broadleaf weeds, including common chickweed (Stellaria media L.), henbit (Lamium amplexicaule L.), and field pansy (Viola rafinesquei Greene) (Dupont, 2004; McCullough and Hart, 2008; Monsanto, 2008; Morton et al., 2009). Simazine is a photosynthesis inhibitor used for controlling numerous grassy and broadleaf weeds and may be safely applied to established bermudagrass during spring greenup (Johnson, 1982; Tworkoski et al., 2000; Syngenta, 2008). Simazine is efficacious for postemergence weed control, but treatments may also have significant soil residual activity that may affect turfgrass seedling establishment (Tworkoski et al., 2000; Cummings et al., 2009; Hixson et al., 2009). Reseeding bermudagrass over areas once occupied by patches of weeds may be desirable following rimsulfuron, simazine, or sulfosulfuron treatments. Therefore, these herbicides may be used for renovating bermudagrass with other mixed species to reestablish bermudagrass turf (McCarty et al., 2005; McCullough and Hart, 2008). The objective of field experiments was to investigate bermudagrass reseeding intervals following rimsulfuron, simazine, and sulfosulfuron applications.

\section{Materials and Methods}

Experiments were conducted on mature tall fescue from June to Aug. 2009 at the University of Georgia in Griffin, GA, and the North Georgia Turf Sod Farm in Whitesburg, GA. Experiments in Whitesburg were located $\approx 50$ miles northwest of the University of Georgia campus in Griffin. Soil in Griffin was a Cecil sandy loam with $4.6 \%$ organic matter and a $\mathrm{pH}$ of 6.0 , while soil in Whitesburg was a Masada fine sandy loam with $4.0 \%$ organic matter and a $\mathrm{pH}$ of 6.5. Tall fescue cultivars were 'Rebel Supreme' and an unknown at Whitesburg and Griffin, respectively. Irrigation at each location was applied to prevent wilt, and both sites were mowed weekly with a rotary mower at $6.4 \mathrm{~cm}$ height with clippings returned. Experimental design was a randomized complete block with four replications. Treatments included five herbicides at four application timings before bermudagrass seeding. Rimsulfuron (TranXit 25DF; Dupont Corp., Montvale, NJ) was applied at 0.02 or $0.04 \mathrm{~kg}$ a.i./ha, sulfosulfuron (Certainty 75WDG; Monsanto, St. Louis, MO) was applied at 0.035 or $0.07 \mathrm{~kg}$ a.i./ha, and simazine (Princep 4L; Syngenta Corp., Greensboro, NC) was applied at $2.2 \mathrm{~kg}$ a.i./ha. Rimsulfuron and sulfosulfuron were applied with a nonionic surfactant at $0.25 \%$ (v/v; Chem-Nut 80-20 Nonionic Surfactant, Albany, GA). Herbicides were applied 0, 2, 4, or 6 weeks before seeding. Application dates are presented in Table 1. Herbicide rates were selected from label recommendations for bermudagrass and the simazine treatment was chosen based on the high label rate (Dupont, 2004; Monsanto, 2008; Syngenta, 2008). A broadcast glyphosate (Roundup Pro; Monsanto Co., St. Louis, MO) application was made at $2.2 \mathrm{~kg}$ a.i./ha 7 days before seeding to kill existing vegetation and facilitate visual assessment of bermudagrass seedling cover. Treatments were applied to $1 \times 3-\mathrm{m}$ plots by making two passes in opposite directions with a single nozzle $\mathrm{CO}_{2}$-pressured sprayer calibrated to deliver $375 \mathrm{~L} \cdot \mathrm{ha}^{-1}$ with a $9504 \mathrm{E}$ flat-fan nozzle at $220 \mathrm{kPa}$ (Tee Jet; Spraying Systems Co., Roswell, GA). Bermudagrass was seeded at $\approx 49 \mathrm{~kg} \cdot \mathrm{ha}^{-1}$ on May 18 and May 27 in Griffin and Whitesburg, respectively. Bermudagrass was a blend of 'Mowhawk', Sultan', and 'Sydney' (Bermuda Triangle; Pennington Seed Inc., Madison, GA) and was seeded in a 4:1 mixture by weight of 5-2-0 (N-P-K) fertilizer (Milorganite, Milwaukee, WI) and seed by weight, respectively. Vertical mowing was conducted on the day of seeding in Griffin to a depth of $1.3 \mathrm{~cm}$. Bermudagrass was seeded over the test area with a $0.9 \mathrm{~m}$ wide drop spreader. Treatments scheduled for the day of seeding were applied immediately after seeding. The seeded area was irrigated daily to promote germination and establishment. Bermudagrass cover was assessed visually, as Yelverton et al. (2009) reported that visual ratings of herbicide responses in turf were less variable than those measured using the line intersect method or digital image analysis. Bermudagrass cover was evaluated two, three, four, six, and eight weeks after treatment on a percentage scale where 0 equaled no cover and 100 equaled complete plot cover. Results were converted to percentage of the untreated. Data were subjected to analysis of variance and means were separated with Fisher's Protected LSD test at the $0.05 P$ level. 
Table 1. Herbicide application and seeding dates in field experiments, 2009, in Griffin, GA, and Whitesburg, GA.

\begin{tabular}{lcc}
\hline${\text { Application Timing }(\text { WBS })^{\mathrm{z}}}^{\mathrm{a}}$ & Griffin, GA & Whitesburg, GA \\
\hline 0 & May 18 & May 27 \\
2 & May 5 & May 12 \\
4 & Apr. 22 & Apr. 28 \\
6 & Apr. 8 & Apr. 15 \\
Glyphosate Application & May 11 & May 21 \\
Seeding date & May 18 & May 27 \\
\hline
\end{tabular}

${ }^{\mathrm{z}} \mathrm{WBS}=$ Weeks before seeding.

\section{Results and Discussion}

Location by treatment interaction was not detected for any observation, and thus, results were pooled over locations. Seedling cover for untreated bermudagrass was $0 \%, 22 \%$, $41 \%, 63 \%$, and $80 \%$ by two, three, four, six, and eight weeks after seeding, respectively (Table 2). Herbicide by application timing interaction was not detected on any observation, and therefore, results are presented by main effect.

Herbicide application timing. Bermudagrass cover at three weeks after seeding was reduced from herbicide applications made closer to seeding dates (Table 2). By three weeks after seeding, bermudagrass cover was $52 \%$ of the untreated with herbicides applied six weeks before seeding while other timings reduced cover to $15 \%$ to $37 \%$ of the untreated. By four weeks after seeding, bermudagrass establishment was significantly inhibited from treatments made the day of seeding or two weeks before, while earlier herbicide timings were similar. Bermudagrass cover was reduced to $15 \%, 53 \%, 81 \%$, and $90 \%$ of the untreated from herbicides applied zero, two, four, or six weeks before seeding, respectively. By six weeks after seeding, bermudagrass cover was $34 \%$,
$70 \%, 80 \%$, and $92 \%$ of the untreated from herbicides applied zero, two, four, or six weeks before seeding, respectively. By eight weeks after seeding, bermudagrass cover was $72 \%$ of the untreated from herbicides applied the day of seeding while other regimes were similar, averaging $90 \%$ of the untreated.

Herbicides and rates. Differences between rimsulfuron rates were not detected for bermudagrass cover on any date (Table 2). Sulfosulfuron rates were similar on all dates, but bermudagrass cover reduction from simazine was $14 \%$ greater than the low sulfosulfuron rate at four weeks after seeding. By six weeks after seeding, simazine significantly reduced bermudagrass cover to $59 \%$ of the untreated compared with at least $74 \%$ from both sulfosulfuron rates and the low rimsulfuron rate. Rimsulfuron treatments at $0.04 \mathrm{~kg}$ a.i./ha had similar bermudagrass cover to simazine on all dates. By eight weeks after seeding, differences among herbicides were not detected, suggesting application timing was more critical for bermudagrass establishment than treatment rates. Bermudagrass injury during establishment has been reported from herbicide applications. Researchers noted that trifloxysulfuron applied one week before seeding injured bermudagrass greater than $30 \%$ and reduced establish-

Table 2. Effects of herbicides and application timing on bermudagrass establishment in field experiments in Griffin, GA, and Whitesburg, GA. Different letters indicate a significant difference according to Fisher's Protected LSD test at the $0.05 P$ level.

\begin{tabular}{|c|c|c|c|c|c|}
\hline \multirow[b]{2}{*}{ Application timing } & & \multicolumn{4}{|c|}{ Bermudagrass cover $\left(\mathrm{WAS}^{\mathrm{z}}\right)$} \\
\hline & & 3 & 4 & 6 & 8 \\
\hline WBS $^{y}$ & & \multicolumn{4}{|c|}{$\%$ of untreated ${ }^{x}$} \\
\hline 0 & & $9 \mathrm{c}$ & $15 \mathrm{c}$ & $34 \mathrm{c}$ & $72 \mathrm{~b}$ \\
\hline 2 & & $28 \mathrm{~b}$ & $53 \mathrm{~b}$ & $74 \mathrm{~b}$ & $86 \mathrm{a}$ \\
\hline 4 & & $37 \mathrm{~b}$ & $81 \mathrm{a}$ & $80 \mathrm{~b}$ & $91 \mathrm{a}$ \\
\hline 6 & & $52 \mathrm{a}$ & $90 \mathrm{a}$ & $92 \mathrm{a}$ & $94 \mathrm{a}$ \\
\hline Treatment $^{\mathrm{w}}$ & Rate (kg a.i/ha) & & & & \\
\hline \multirow{2}{*}{ Rimsulfuron } & 0.02 & $29 \mathrm{ab}$ & $54 \mathrm{~b}$ & $75 \mathrm{a}$ & $87 \mathrm{a}$ \\
\hline & 0.04 & $25 \mathrm{~b}$ & $48 \mathrm{~b}$ & $67 \mathrm{ab}$ & $85 \mathrm{a}$ \\
\hline Simazine & 2.24 & $29 \mathrm{ab}$ & $57 \mathrm{~b}$ & $59 \mathrm{~b}$ & $81 \mathrm{a}$ \\
\hline \multirow[t]{2}{*}{ Sulfosulfuron } & 0.035 & $43 \mathrm{a}$ & $71 \mathrm{a}$ & $73 \mathrm{a}$ & $85 \mathrm{a}$ \\
\hline & 0.07 & $31 \mathrm{ab}$ & $60 \mathrm{ab}$ & $74 \mathrm{a}$ & $90 \mathrm{a}$ \\
\hline Timing & & $*$ & $*$ & $*$ & $*$ \\
\hline Treatment & & * & * & * & NS \\
\hline Timing $\times$ treatment & & NS & NS & NS & NS \\
\hline
\end{tabular}

${ }^{\mathrm{z}} \mathrm{WAS}=$ weeks after seeding

${ }^{\mathrm{y}} \mathrm{WBS}=$ weeks before seeding.

${ }^{x}$ Bermudagrass cover for the untreated was $0 \%, 22 \%, 42 \%, 68 \%$, and $80 \%$ by $2,3,4,6$, and 8 weeks after seeding, respectively. Bermudagrass seeded was a blend of 'Mowhawk', 'Sultan', and 'Sydney' (Bermuda Triangle, Pennington Seed, Inc., Madison, GA).

wimsulfuron and sulfosulfuron were applied with a nonionic surfactant at $0.25 \%(\mathrm{v} / \mathrm{v}$; Chem Nut $80-20$, a mixture of alkyl and arlkylaryl polyoxyethylene glycol, $80 \%$, Chem Nut, Inc., Albany, GA). Herbicides applied were TranXit 25DF (rimsulfuron; Dupont Corp., Montvale, NJ); Princep 4L (simazine; Syngenta Corp., Greensboro, NC); and Certainty 75WDG (sulfosulfuron; Monsanto, St. Louis, MO). ment (Willis et al., 2007). Foramsulfuron, metsulfuron, and sulfosulfuron were reported safe to apply one or three weeks after seeding but rimsulfuron caused significant bermudagrass injury (Willis et al., 2008). In Arkansas, injury to bermudagrass seedlings was reported from MSMA applications with flazasulfuron, foramsulfuron, metribuzin, or trifloxysulfuron, but injury was temporary and generally did not reduce overall bermudagrass establishment after 30 days (Richardson et al., 2005). Sulfosulfuron application timing before seeding has shown to influence establishment of cool-season grasses. Rutledge et al. (2009) noted sulfosulfuron at 13 or $26 \mathrm{~g}$ a.i./ha applied the day of seeding or 2 weeks before significantly reduced 'Penncross' creeping bentgrass (Agrostis stolonifera L.) establishment, but applications made three weeks before seeding were safe. It was also reported that sulfosulfuron applied at $52 \mathrm{~g}$ a.i./ha was not safe at any timing before seeding. In New Jersey, Lycan and Hart (2005) noted sulfosulfuron applied one week before seeding creeping bentgrass and Kentucky bluegrass (POa pratensis L.) reduced cover to $53 \%$ and $56 \%$ of the untreated, respectively, by seven weeks after seeding but was less injurious to perennial ryegrass. It was concluded that perennial ryegrass may be safely reseeded two weeks after sulfosulfuron applications at 34 or $67 \mathrm{~g}$ a.i./ha, but creeping bentgrass and Kentucky bluegrass may require up to four weeks to safely reestablish in treated areas. Simazine is generally safe for actively growing bermudagrass, but soil residual activity may influence turf establishment (Lawson et al., 2002; Syngenta, 2008; Cummings et al., 2009). In Georgia, simazine applied at 1.1, 2.2, or $4.4 \mathrm{~kg}$ a.i./ha the day of centipedegrass seeding [Eremochloa ophiuroides (Munro) Hack.] caused less than $15 \%$ injury after five weeks (Ferrell et al., 2003). Simazine applied during establishment has shown not to reduce centipedegrass, St. Augustinegrass [Stenotaphrum secundatum (Walter) Kuntze], or zoysiagrass [Zoysia matrella (L.) Merr.] cover from the untreated, but may have potential to inhibit growth of immature turf (Engel et al., 1968; Johnson, 1973; Johnson, 1982; Gannon et al., 2004). Simazine applications before seeding appear to temporarily delay bermudagrass establishment, with more potential than rimsulfuron and sulfosulfuron, but residual activity could vary depending on application rate, soil, and environmental conditions (Engel et al., 1968; Johnson, 1973; Cummings et al., 2009; Hixson et al., 2009). These factors may also influence efficacy of application timings relative to bermudagrass seeding and warrant further investigation.

\section{Conclusions}

Turfgrass managers applying rimsulfuron, simazine, or sulfosulfuron should delay reseeding bermudagrass into treated areas. These herbicides applied two weeks before seeding have potential to inhibit common bermudagrass establishment, but delaying 
reseeding by four to six weeks appears safe for end-users.

\section{Literature Cited}

Beard, J.B. 1973. Warm season turfgrasses, p. 132142. In: Turfgrass: Science and Culture. Prentice-Hall, Englewood Cliffs, NJ.

Chaleff, R.S. and C.J. Mauvais. 1984. Acetolactate synthase is the site of action of two sulfonylurea herbicides in higher plants. Science 224:14431445.

Cummings, H.D., J.B. Weber, F.H. Yelverton, and R.B. Leidy. 2009. Downward mobility of ${ }^{14} \mathrm{C}$ labeled simazine in a bermudagrass system vs. a fallow soil system. Crop Sci. 49:704-713.

Dupont, 2004. TranXit ${ }^{\circledR}$ GTA Herbicide Label. Montvale, NJ 07045.

Engel, R.E., C.R. Funk, and D.A. Kinney. 1968. Effect of varied rates of atrazine and simazine on the establishment of several zoysia strains. Agron. J. 60:261-262.

Ferrell, J.A., T.R. Murphy, W.K. Vencill, and W.R Guerke. 2003. Effects of postemergence herbicides on centipedegrass seed production. Weed Technol. 17:871-875.

Gannon, T.W., F.H. Yelverton, H.D. Cummings, and J.S. McElroy. 2004. Establishment of seeded centipedegrass (Eremochloa ophiuroides) in utility turf areas. Weed Technol. 18:641-647.

Hixson, A.C., W. Shi, J.B. Weber, F.H. Yelverton, and T.W. Rufty. 2009. Soil organic matter changes in turfgrass systems affect binding and biodegradation of simazine. Crop Sci. 49:1481-1488.
Johnson, B.J. 1973. Establishment of centipedegrass and St. Augustinegrass with the aid of chemicals. Agron. J. 65:959-962.

Johnson, B.J. 1982. Simazine formulation treatments on control of winter weeds in bermudagrass turf. Agron. J. 74:881-886.

Lawson, R.N., J.B. Unruh, and B.J. Brecke. 2002. Lawn burweed (Soliva pterosperma) control in hybrid bermudagrass (Cynodon dactylon $\times C$. transvaalensis) and common centipedegrass (Eremochloa ophiuroides). Weed Technol. 16: 84-87.

Lycan, D.W., and S.E. Hart. 2005. Cool-season turfgrass reseeding intervals for sulfosulfuron. Appl. Turfgrass Sci. doi: 10.1094/ATS-20050808-01-RS.

McCarty, B., T. Murphy, T.T. Whitwell, and F. Yelverton. 2005. Turfgrass weeds, p. 663-703 In: McCarty, L.B. (ed.). Best golf course management practices, 2nd ed. Prentice-Hall, Upper Saddle River, NJ.

McCullough, P.E. and S.E. Hart. 2008. Roughstalk bluegrass and tall fescue control in Kentucky bluegrass with sulfosulfuron. Appl. Turfgrass Sci. doi: 10.1094/ATS-2008-0625-01-RS.

Monsanto, 2008. Certainty® Herbicide Label. St. Louis, MO 63167.

Morton, D.E., D.V. Weisenberger, and Z.J. Reicher. 2009. Response of eight cultivars of roughstalk bluegrass to bispyribac or sulfosulfuron. Appl. Turfgrass Sci. doi: 10.1094/ATS2009-0831-01-RS.

National Turfgrass Evaluation Program. 2008. 2007 National Bermudagrass Test. 21 Oct. 2009. $<$ http://www.ntep.org/data/bg07/bg07_09-1/ bg0709t01a.txt $>$.
Richardson, M.D., D.E. Karcher, J.W. Boyd, J.H. McCalla, and J.W. Landreth. 2005. Tolerance of 'Riviera' bermudagrass to MSMA tankmixtures with postemergence herbicides during establishment from seed. Appl. Turfgrass Sci. doi: 10.1094/ATS-2005-0718-01-RS.

Rutledge, J.M., D.V. Weisenberger, and Z.J. Reicher. 2009. Effect of sulfosulfuron on 'Penncross' creeping bentgrass seedlings when applied before or after seeding. Appl. Turfgrass Sci. doi: 10.1094/ATS-2009-0710-01-RS.

Syngenta. 2008. Princep ${ }^{\circledR}$ Herbicide Label. Greensboro, NC 27419.

Toler, J.E., T.G. Willis, A.G. Estes, and L.B. McCarty. 2007. Postemergent annual bluegrass control in dormant nonoverseeded bermudagrass turf. HortScience 42:670-672.

Tworkoski, T.J., W.V. Welker, and G.D. Vass. 2000. Soil residues following repeat applications of diuron, simazine, and terbacil. Weed Technol. 14:191-196.

Willis, J.B., D.B. Ricker, and S.D. Askew. 2007. Sulfonylurea herbicides applied during early establishment of seeded bermudagrass. Weed Technol. 21:1035-1038.

Willis, J.B., D.B. Ricker, and S.D. Askew. 2008 'Riviera' bermudagrass response to preseeding applications of sulfonylurea herbicides. Appl. Turfgrass Sci. doi: 10.1094/ATS-20080916-01-RS.

Yelverton, F.H., J.A. Hoyle, T.W. Gannon, and L.S. Warren. 2009. Plant counts, digital image analysis, and visual ratings for estimating weed control in turf: Are they correlated? Proc. South Weed Sci. Soc. 62:399. 